\title{
Photovoltaic Performance of Dye-Sensitized Solar Cells Containing ZnO Microrods
}

\author{
Seong Il Cho ${ }^{1,+}$, Hye Kyeong Sung ${ }^{2,+}$, Sang-Ju Lee ${ }^{3}$, Wook Hyun Kim ${ }^{3}$, Dae-Hwan Kim ${ }^{3, *(1)}$ \\ and Yoon Soo Han ${ }^{1, *}$ \\ 1 School of Advanced Materials and Chemical Engineering, Daegu Catholic University, \\ Gyeongbuk 38430, Korea; pokw1231@naver.com \\ 2 Department of Organic Material Science and Engineering, Pusan National University, Busan 46241, Korea; \\ amrm1995@naver.com \\ 3 Division of Energy Technology, Daegu Gyeongbuk Institute of Science and Technology (DGIST), \\ Daegu 42988, Korea; tglee@dgist.ac.kr (S.-J.L.); kwh1980@dgist.ac.kr (W.H.K.) \\ * Correspondence: monolith@dgist.ac.kr (D.-H.K.); yshancu@cu.ac.kr (Y.S.H.); Tel.: +82-53-785-3720 (D.-H.K.); \\ +82-53-850-2773 (Y.S.H.); Fax: +82-53-785-3739 (D.-H.K.); +82-53-359-6662 (Y.S.H.) \\ + These authors contributed equally to this work.
}

Received: 3 November 2019; Accepted: 18 November 2019; Published: 20 November 2019

check for updates

\begin{abstract}
At an elevated temperature of $90^{\circ} \mathrm{C}$, a chemical bath deposition using an aqueous solution of $\mathrm{Zn}\left(\mathrm{NO}_{3}\right)_{2} \cdot 6 \mathrm{H}_{2} \mathrm{O}$ and $\left(\mathrm{CH}_{2}\right)_{6} \mathrm{~N}_{4}$ resulted in the formation of both nanoflowers and microrods of $\mathrm{ZnO}$ on F-doped $\mathrm{SnO}_{2}$ glass with a seed layer. The nanoflowers and microrods were sensitized with dyes for application to the photoelectrodes of dye-sensitized solar cells (DSSCs). By extending the growth time of $\mathrm{ZnO}$, the formation of nanoflowers was reduced and the formation of microrods favored. As the growth time was increased from 4 to 6 and then to $8 \mathrm{~h}$, the open circuit voltage $\left(V_{o c}\right)$ values of the DSSCs were increased, whilst the short circuit current $\left(J_{s c}\right)$ values varied only slightly. Changes in the dye-loading amount, dark current, and electrochemical impedance were monitored and they revealed that the increase in $V_{o c}$ was found to be due to a retardation of the charge recombination between photoinjected electrons and $\mathrm{I}_{3}{ }^{-}$ions and resulted from a reduction in the surface area of $\mathrm{ZnO}$ microrods. A reduced surface area decreased the dye contents adsorbed on the $\mathrm{ZnO}$ microrods, and thereby decreased the light harvesting efficiency (LHE). An increase in the electron collection efficiency attributed to the suppressed charge recombination counteracted the decreased LHE, resulting in comparable $J_{s c}$ values regardless of the growth time.
\end{abstract}

Keywords: dye-sensitized solar cell; $\mathrm{ZnO}$; nanoflowers; microrods

\section{Introduction}

Photovoltaic cells convert solar energy into direct current electricity using p-type and n-type semiconductors. Traditionally, solid-state junction devices, usually made of silicon, have dominated this field, drawing on the experience and material availability arising from the semiconductor industry. The dominance of inorganic solid-state junction cells is being challenged by the advent of third-generation photovoltaic cells such as dye-sensitized solar cells (DSSCs), polymer solar cells, and perovskite solar cells [1-3]. DSSCs based on nanoporous $\mathrm{TiO}_{2}$ films have been extensively researched due to their comparable photovoltaic efficiency, potentially low production cost, low toxicity, and rapid manufacturing process. In addition, the advantages of DSSCs for real-world applications, including transparent and multicolor options, or both, easy architectural integration, and short energy payback time have drawn attention.

The general DSSC consists of a dye-adsorbed semiconductor electrode (i.e., $\mathrm{TiO}_{2}$ photoelectrode), an electrolyte, and a Pt-coated counter electrode $[1,4]$. The $\mathrm{TiO}_{2}$ photoelectrodes in the cells play 
an important role in the photovoltaic efficiency. Highly porous $\mathrm{TiO}_{2}$ films provide extended surface area for dye adsorption resulting in the enhanced light harvesting efficiency (LHE) of DSSCs. $\mathrm{TiO}_{2}$, as an n-type semiconductor, is also a good transporter of the electrons injected from the photoexcited dyes. As another n-type semiconductor, $\mathrm{ZnO}$ has a band gap energy of $3.3 \mathrm{eV}$, similar to that of $\mathrm{TiO}_{2}(3.2 \mathrm{eV})$, and has much higher electron diffusivity than $\mathrm{TiO}_{2}$. It also has a high electron mobility of $115-155 \mathrm{~cm}^{2}$ $\mathrm{V}^{-1} \mathrm{~s}^{-1}$, which is favorable for effective electron transport through the $\mathrm{ZnO}$ layer and for reduction of the charge recombination rate [5,6]. In addition, the diverse morphologies of $\mathrm{ZnO}$ including nanorods, nanowires, nanosheets, nanobolts, or nanoflowers allows for various designs of photoelectrodes for $\mathrm{ZnO}$ based DSSCs. The diverse morphology of $\mathrm{ZnO}$ is attributable to the anisotropic growth of $\mathrm{ZnO}$, unlike the crystalline structure of $\mathrm{TiO}_{2}$ [5-8]. $\mathrm{ZnO}$ is thus considered to be a viable alternative to $\mathrm{TiO}_{2}$ in DSSCs.

The reported power conversion efficiencies (PCEs) of $\mathrm{ZnO}$-based DSSCs range from under $1 \%$ to the highest value of $7.5 \%[5,6,9]$, mainly dependent on the deposition condition and the morphology of nano-structured $\mathrm{ZnO}$. Extensive research on improving the PCE of DSSCs based on the nanostructure of $\mathrm{ZnO}$ has been conducted since the first report on dye-sensitized $\mathrm{ZnO}$ [10], but little attention has been given to the use of $\mathrm{ZnO}$ microrods. To the best of our knowledge, DSSCs with $\mathrm{ZnO}$ microrods as photoelectrodes have never been reported. In this study, $\mathrm{ZnO}$ microrods grown on F-doped $\mathrm{SnO}_{2}$ (FTO) glass were prepared through a chemical bath deposition. Dye-sensitized microrods were utilized as the photoelectrodes of DSSCs and their photovoltaic performance was examined.

\section{Materials and Methods}

\subsection{Materials}

Commercial FTO (sheet resistance $\sim 7$ /square) glass (TCO22-7), N719 dye (Ruthenizer 535-bisTBA), hot-melt adhesive (SX1170-60PF, Surlyn), and iodide-based electrolytes (AN-50) were purchased from Solaronix. Zinc acetate dehydrate $\left[\mathrm{Zn}\left(\mathrm{CH}_{3} \mathrm{COO}\right)_{2} \cdot 2 \mathrm{H}_{2} \mathrm{O}\right]$, zinc nitrate hexahydrate $\left[\mathrm{Zn}\left(\mathrm{NO}_{3}\right)_{2} \cdot 6 \mathrm{H}_{2} \mathrm{O}\right]$, and hexamethylenetetramine [HMTA, $\left.\left(\mathrm{CH}_{2}\right) \mathrm{N}_{4}\right]$ (Sigma-Aldrich Co.) were used to form $\mathrm{ZnO}$ microrods. We used Pt paste (PT-1, Dyesol-Timo) as the source for the counter electrode. All the above reagents and materials were used without further purification.

\subsection{Preparation of DSSCS}

To prepare the working $\mathrm{ZnO} / \mathrm{FTO}$ electrodes, the FTO glass was cleaned in a detergent solution with sonication for $20 \mathrm{~min}$ and then thoroughly rinsed with deionized (DI) water and ethanol. To deposit a seed layer, we spin-coated a solution of $\mathrm{Zn}\left(\mathrm{CH}_{3} \mathrm{COO}\right)_{2} \cdot 2 \mathrm{H}_{2} \mathrm{O}$ in ethanol $(5 \mathrm{mM})$ on the cleaned FTO glass at $500 \mathrm{rpm}$ for $5 \mathrm{~s}$, at $3000 \mathrm{rpm}$ for $30 \mathrm{~s}$, and at $500 \mathrm{rpm}$ for $5 \mathrm{~s}$. They were then dried on coated glass on a preheated hot plate at $150{ }^{\circ} \mathrm{C}$ for $15 \mathrm{~min}$. After this process was repeated three times, the glass was annealed at $350{ }^{\circ} \mathrm{C}$ for $15 \mathrm{~min}$. The FTO glass with the seed layer was immersed in an aqueous solution of $\mathrm{Zn}\left(\mathrm{NO}_{3}\right)_{2} \cdot 6 \mathrm{H}_{2} \mathrm{O}(35 \mathrm{mM})$ and $\mathrm{HMTA}(35 \mathrm{mM})$ at $90{ }^{\circ} \mathrm{C}$ for $4-10 \mathrm{~h}$ to form $\mathrm{ZnO}$ microrods on the FTO substrate. The deposition area was adjusted by masking using Kapton tape. After the deposition, the films were taken out of the growth solution and rinsed with deionized water and ethanol. Subsequently, the ZnO microrods on the FTO glass were annealed at $450{ }^{\circ} \mathrm{C}$ for $30 \mathrm{~min}$. Dye-sensitized $\mathrm{ZnO} / \mathrm{FTO}$ photoelectrodes were prepared through the conventional soaking method, i.e., the $\mathrm{ZnO} / \mathrm{FTO}$ films were soaked in a $0.5 \mathrm{mM}$ dye (N719) solution (ethanol) for $20 \mathrm{~min}$.

Two small holes were formed in the FTO glasses and the glasses were thoroughly cleaned with ultrasonification. Pt paste was coated on the cleaned FTO glass via the doctor-blade method and then calcined at $400{ }^{\circ} \mathrm{C}$ for $30 \mathrm{~min}$. The resulting counter electrodes and the working $\mathrm{ZnO} / \mathrm{FTO}$ electrodes were sealed using a $60 \mu \mathrm{m}$ thick Surlyn. By injecting the electrolyte into the cells through one of the two small holes in the counter electrodes we could prepare ZnO-based DSSCs with a $25 \mathrm{~mm}^{2}$ active area. Figure 1 shows a schematic illustration of a ZnO-based DSSC and electron flow when the device is exposed to light. 


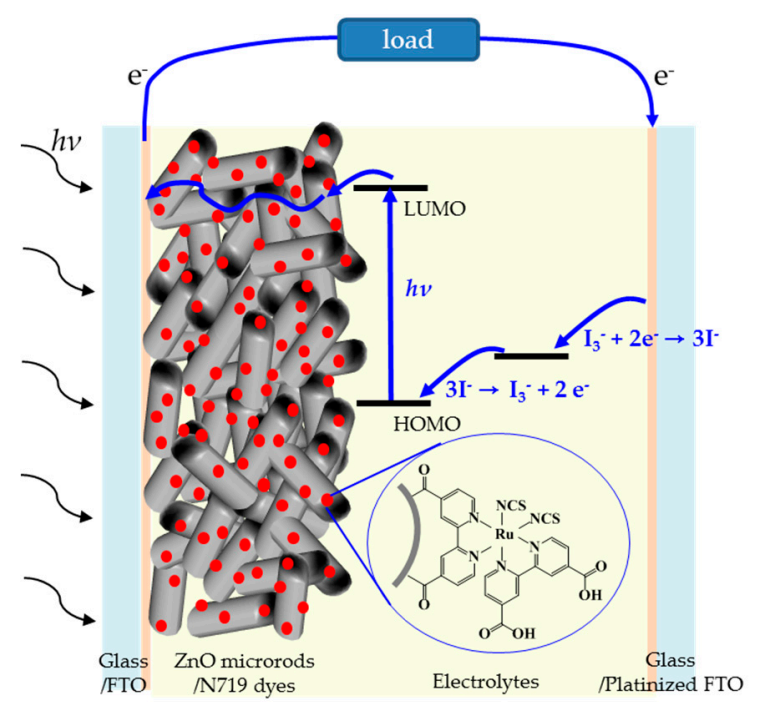

Figure 1. Structure of ZnO-based dye-sensitized solar cells (DSSC) and mechanism for light energy conversion into electric energy.

\subsection{Measurements}

The morphology of the $\mathrm{ZnO}$ microrods was visualized by field emission scanning electron microscopy (FE-SEM; S-4800, Hitachi High-Technology, Tokyo, Japan). A CompactStat potentiostat (Ivium Technologies B.V., Eindhoven, The Netherlands) and a PEC-L01 solar simulator system equipped with a $150 \mathrm{~W}$ xenon arc lamp (Peccell Technologies, Inc., Yokohama, Japan) were used to measure the photocurrent and photovoltage. To adjust the light intensity to $1 \mathrm{sun}\left(100 \mathrm{~mW} / \mathrm{cm}^{2}\right)$ a silicon photodiode (PEC-SI01, Peccell Technologies, Inc., Yokohama, Japan) was utilized. The UV-visible absorbance was measured using a spectrophotometer (NEOSYS 2000, Seoul, SINCO, Korea). An electrochemical analyzer (CompactStat, Ivium Technologies B.V., Eindhoven, The Netherlands) was used for the electrochemical impedance spectroscopic (EIS) analysis. The active area of the $\mathrm{ZnO}$ layer was measured using a digital microscope camera (OLYMPUS SZ61) equipped with image analysis software.

\section{Results and Discussion}

\subsection{Morphological Characteristics of $\mathrm{ZnO}$ Layers with Growth Time}

Nano- and micro-structured $\mathrm{ZnO}$ layers were formed through Equations (1)-(4) on the FTO substrates when the seeded FTO glass was immersed into the growth solution comprised of zinc nitrate and HMTA $\left[\left(\mathrm{CH}_{2}\right) \mathrm{N}_{4}\right]$ at $90^{\circ} \mathrm{C}$.

$$
\begin{gathered}
\left(\mathrm{CH}_{2}\right) \mathrm{N}_{4}(\mathrm{aq})+6 \mathrm{H}_{2} \mathrm{O}(\mathrm{l}) \rightarrow 4 \mathrm{NH}_{3}(\mathrm{~g})+6 \mathrm{HCHO}(\mathrm{aq}) \\
\mathrm{NH}_{3}(\mathrm{~g})+\mathrm{H}_{2} \mathrm{O}(\mathrm{l}) \rightarrow \mathrm{NH}_{4}^{+}(\mathrm{aq})+\mathrm{OH}^{-}(\mathrm{aq}) \\
\mathrm{Zn}^{2+}(\mathrm{aq})+2 \mathrm{OH}^{-}(\mathrm{aq}) \rightarrow \mathrm{Zn}(\mathrm{OH})_{2}(\mathrm{~s}) \\
\mathrm{Zn}(\mathrm{OH})_{2}(\mathrm{~s}) \rightarrow \mathrm{ZnO}(\mathrm{s})+\mathrm{H}_{2} \mathrm{O}(\mathrm{l})
\end{gathered}
$$

HTMA was hydrolyzed, i.e., reacted with water, to yield $\mathrm{HCHO}$ and $\mathrm{NH}_{3} . \mathrm{Zn}(\mathrm{OH})_{2}$, precipitated through the reaction between the zinc ions $\left(\mathrm{Zn}^{2+}\right)$ and hydroxide ions $\left(\mathrm{OH}^{-}\right)$provided from zinc nitrate and ammonium hydroxide (see Equation (2)), respectively, and then dehydrated to form 
$\mathrm{ZnO}$. Generally, the concentration of the CBD solution determines the density of a nanostructure, while temperature and growth time affect aspect ratio and morphology of the nanostructure [11-15].

Using a CBD solution comprising zinc nitrate $(35 \mathrm{mM})$ and HMTA $(35 \mathrm{mM})$, we fabricated a mixed layer of $\mathrm{ZnO}$ nanoflowers and microrods at an elevated temperature of $90^{\circ} \mathrm{C}$. Randomly distributed nanoflowers and microrods of $\mathrm{ZnO}$ were formed, as illustrated in Figure 2. As a reference, when the growth temperature was lowered to $75^{\circ} \mathrm{C}$, only $\mathrm{ZnO}$ nanorods, which were dense and vertically aligned, were formed on the FTO glass (not shown here). As the growth time was extended, the number of nanoflowers was reduced whilst the number of microrods increased. The nanoflowers exhibited a length of approximately $0.54-3.43 \mu \mathrm{m}$ and a diameter of 350-650 $\mathrm{nm}$. The length and diameter of the microrods were measured to be approximately $6.2-13.1 \mu \mathrm{m}$ and $2.27-3.55 \mu \mathrm{m}$, respectively. A cross-sectional view of the $\mathrm{ZnO}$ layers on the FTO glass is shown in Figure 3. ZnO layers composed of nanoflowers and microrods were formed on the FTO glass with thicknesses of about 12, 16, 18, and $19 \mu \mathrm{m}$ for growth times of $4,6,8$, and $10 \mathrm{~h}$, respectively.
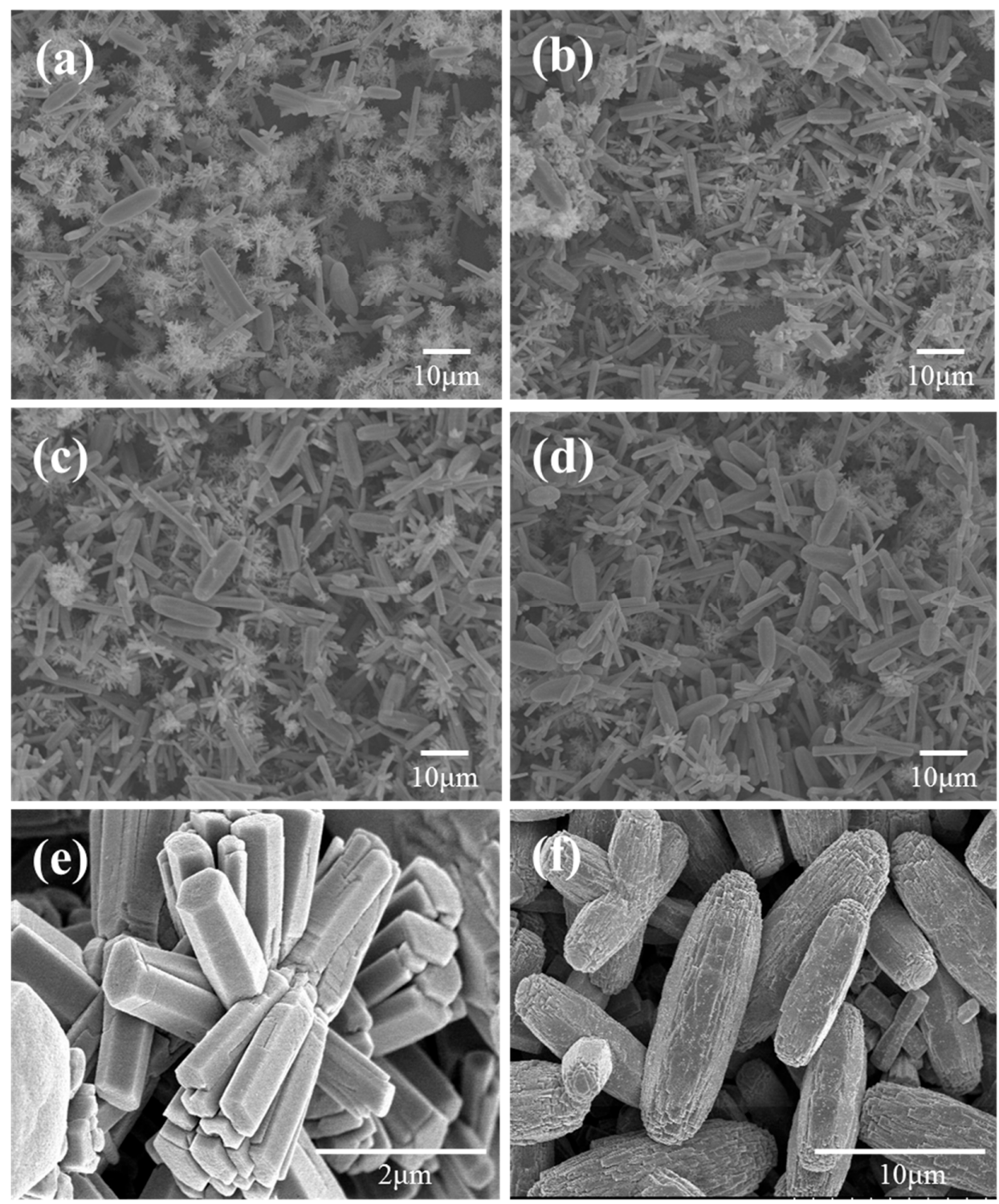

Figure 2. Top-view SEM images of the ZnO layer formed on the FTO glass for (a) $4 \mathrm{~h}$, (b) $6 \mathrm{~h}$, (c) $8 \mathrm{~h}$, and $(\mathbf{d}) 10 \mathrm{~h}$ of growth time. Figures $(\mathbf{e}, \mathbf{f})$ are illustrations of nanoflowers and microrods, respectively. 

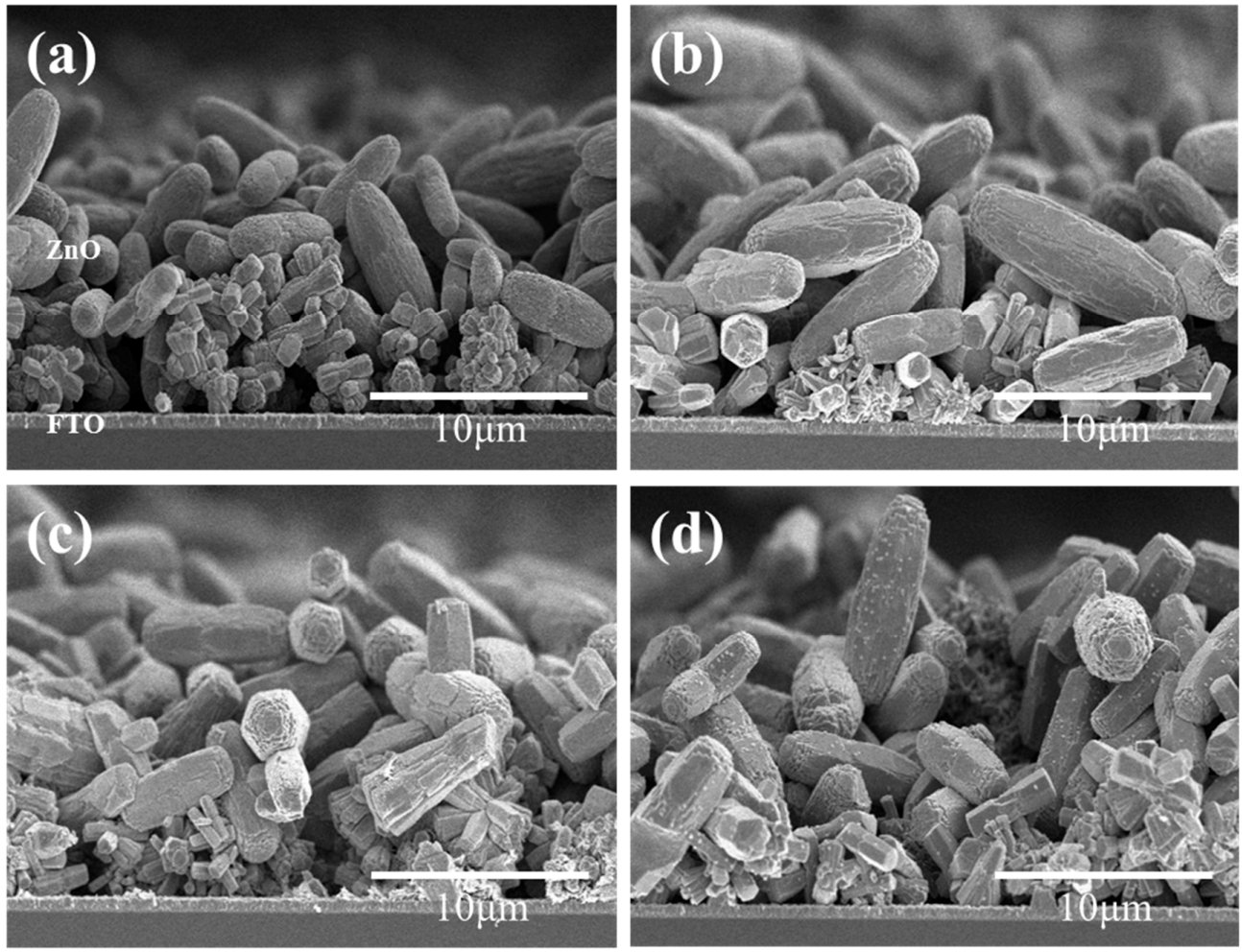

Figure 3. Cross-sectional SEM images of ZnO layer formed on the FTO glass for (a) $4 \mathrm{~h}$, (b) $6 \mathrm{~h}$, (c) $8 \mathrm{~h}$, and (d) $10 \mathrm{~h}$ growth time.

\subsection{Photovoltaic Performance of DSSCs with ZnO Nanoflowers and Microrods}

The ZnO-coated FTO glass was dipped in the ethanolic solution $(0.05 \mathrm{mM})$ of N719 dyes, sensitizing the nanoflowers and microrods and thereby producing sensitized $\mathrm{ZnO}(4,6,8$ or 10)/FTO photoelectrodes, where "(4)" indicates that the growth time of $\mathrm{ZnO}$ was $4 \mathrm{~h}$. DSSCs were fabricated using the sensitized $\mathrm{ZnO} / \mathrm{FTO}$ photoelectrodes, and the effects of the growth time on the cell performance were investigated. Four cells were fabricated for each growth time and the PCE of each cell was measured. Among the four cells fabricated for each growth time, one that showed a PCE similar to the averaged value was chosen. Variation curves of cell performance as a function of the growth time are illustrated in Figure 4. Detailed photovoltaic parameters are compared in Figure S1 and Table S1 in the Supplementary Information. Relatively low PCEs were recorded in the DSSCs based on the nanoflowers and microrods. This could be due to the randomly distributed $\mathrm{ZnO}$ layers that interrupted the transfer of photo-injected electrons to FTO electrodes compared to those that were vertically aligned. The open-circuit voltage $\left(V_{o c}\right)$ values increased with increased growth time, while the fill factor $(F F)$ values were reduced. The $J_{s c}$ value of the DSSCs remained similar for growth times of $4-8 \mathrm{~h}$, but decreased sharply for $10 \mathrm{~h}$ growth time. Overall, the highest PCE value was observed at a growth time of $8 \mathrm{~h}$. In order to explore the higher efficiency of the $\mathrm{ZnO}(8) / \mathrm{FTO}$ DSSC, we set the $\mathrm{ZnO}(4) / \mathrm{FTO}$ DSSC as a reference cell. This is because the $\mathrm{ZnO}(4) / F T O ~ D S S C$ contains the largest number of nanoflowers among our $\mathrm{ZnO} / \mathrm{FTO}$ samples. 

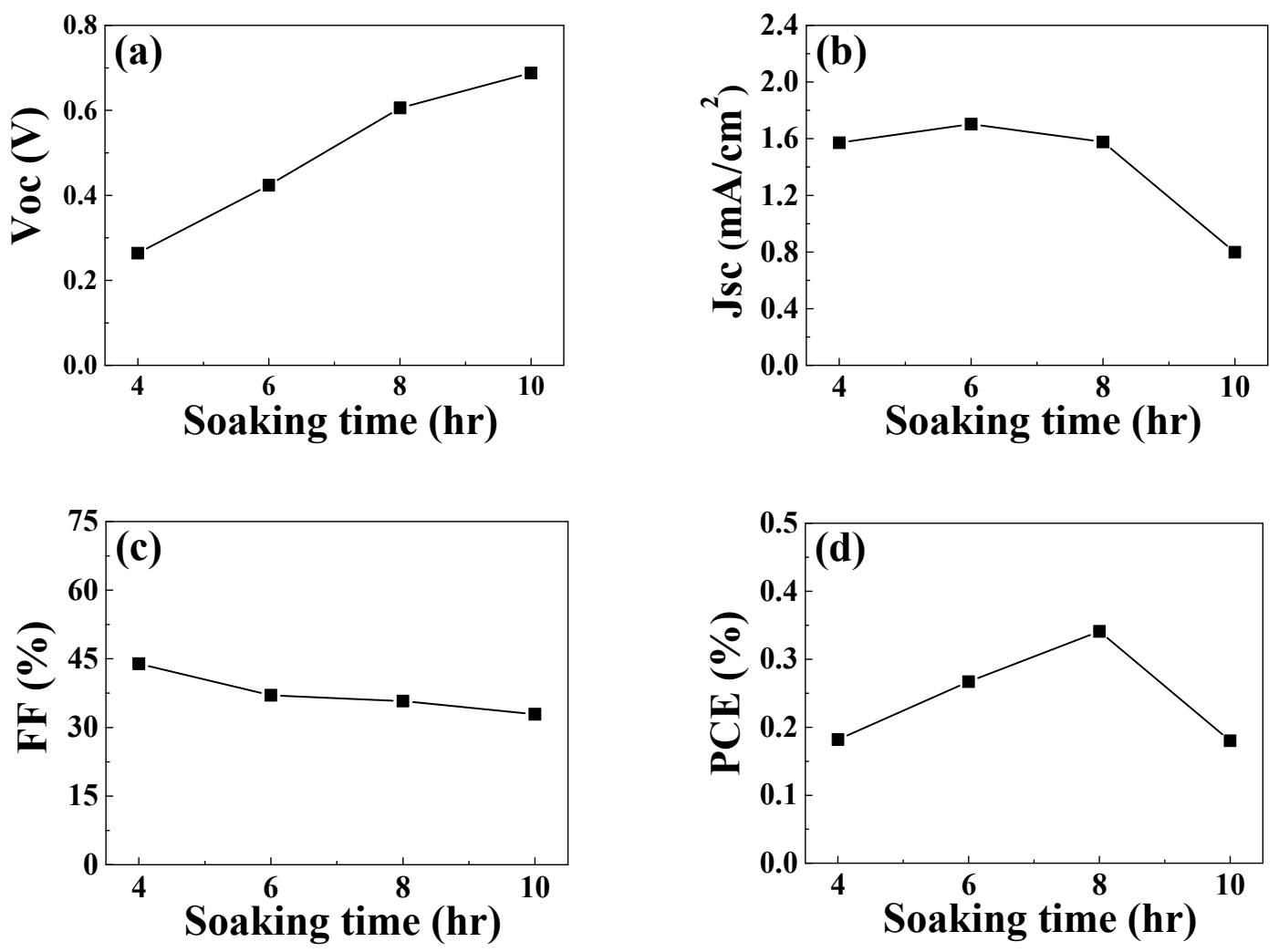

Figure 4. Variation of the photovoltaic performance with growth time: $(\mathbf{a}) J_{s c},(\mathbf{b}) V_{o c},(\mathbf{c})$ Fill factor $(F F)$, and (d) PCE of the DSSCs measured under AM 1.5 irradiation.

Figure 5 presents the current density $(J)$ and voltage $(V)$ curves of the $\mathrm{ZnO}(8) / \mathrm{FTO}$ and the $\mathrm{ZnO}(4) / \mathrm{FTO}$ DSSCs. The DSSC performance is compared in Table 1 . The DSSC with the $\mathrm{ZnO}(8) / \mathrm{FTO}$ photoelectrode showed a PCE of $0.341 \%$, while the reference cell with the $\mathrm{ZnO}(4) / \mathrm{FTO}$ showed a PCE of $0.182 \%$. The improved PCE was mostly due to the increment of the $V_{o c}$. A significant increase in $V_{o c}$ of the $\mathrm{ZnO}(8) / \mathrm{FTO}$ cell is notable compared to the reference cell. Under constant illumination, the $V_{o c}$ value of DSSCs can be expressed as a function of the quasi-Fermi level $\left(E_{F n}\right)$ and to the dark value $\left(E_{F 0}\right)$. This is related to the thermal energy $\left(k_{B} T ; 4.11 \times 10^{-21} \mathrm{~J}\right.$ at $\left.25^{\circ} \mathrm{C}\right)$, the Boltzmann constant $\left(k_{B}\right)$, the absolute temperature $(T)$, the positive elementary charge $\left(e ; 1.602 \times 10^{-19} \mathrm{C}\right)$, the concentration in the dark $\left(n_{0}\right)$, and the free electron density in the $\mathrm{ZnO}$ photoelectrode ( $n$ ), as represented in Equation (5) [16-18]:

$$
V_{o c}=\left(E_{F n}-E_{F 0}\right) / e=\left(k_{B} T / e\right) \cdot \ln \left(n / \mathrm{n}_{0}\right)
$$

It can be seen from Equation (5) that $V_{o c}$ and $n$ are closely correlated. In addition, $n$ is affected by both the electron injection from the photoexcited dyes to the $\mathrm{ZnO}$ conduction bands and the charge recombination between photoinjected electrons and triiodide anion in the electrolyte. Therefore, higher electron injection and lesser back electron transfer is necessary to increase $n$ and thereby to improve $V_{o c}$. To estimate electron injection in the $\mathrm{ZnO} / \mathrm{FTO}$ photoelectrodes, we measured amounts of N719 dyes adsorbed on the surface of $\mathrm{ZnO}$ nanoflowers and microrods using the Beer-Lambert equation [19-21]. The adsorbed amounts of dyes, which were measured using 5 cells, for the $\mathrm{ZnO}(8) / \mathrm{FTO}$ and the $\mathrm{ZnO}(4) / \mathrm{FTO}$ photoelectrodes averaged $2.43 \times 10^{-5}$ and $6.33 \times 10^{-5} \mathrm{~mol} / \mathrm{cm}^{3}$, respectively. About a $60 \%$ reduction in the dye-loading amount was observed in the $\mathrm{ZnO}(8)-\mathrm{ZnO} / \mathrm{FTO}$ compared to the $\mathrm{ZnO}(4) / \mathrm{FTO}$. A decrease in the adsorption of N719 dyes on the photoelectrodes could lead to generating fewer electrons and holes, reducing the total number of photoinjected electrons in the device and thus lowering the $n$ value. 


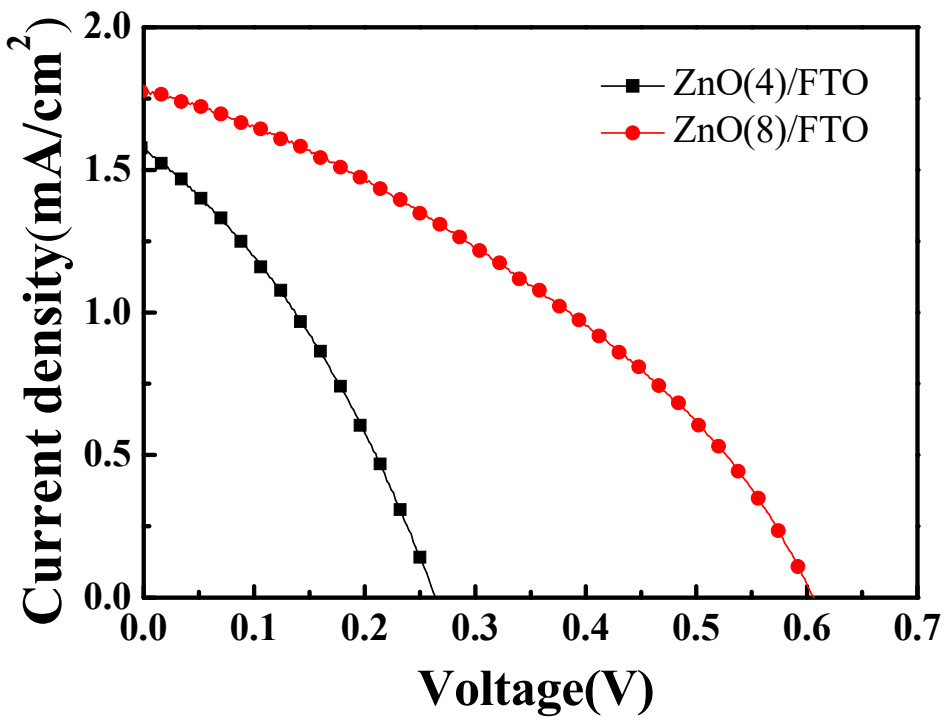

Figure 5. $J-V$ characteristics of DSSCs with $\mathrm{ZnO}(4) / \mathrm{FTO}$ and $\mathrm{ZnO}(8) / \mathrm{FTO}$ photoelectrodes.

Table 1. Photovoltaic properties of DSSCs with $\mathrm{ZnO}(4) / \mathrm{FTO}$ and $\mathrm{ZnO}(8) / \mathrm{FTO}$ photoelectrodes.

\begin{tabular}{ccccccc}
\hline Applied Photoelectrodes & $V_{o c}(\mathbf{m V})$ & $J_{s c}\left(\mathbf{m A} / \mathbf{c m}^{2}\right)$ & $F F(\%)$ & $\eta(\%)$ & $R_{s e}\left(\Omega \mathrm{cm}^{2}\right)$ & $R_{s h}\left(\Omega \mathrm{cm}^{2}\right)$ \\
\hline $\mathrm{ZnO}(4) / F T O$ & 0.264 & 1.572 & 43.94 & 0.182 & 97.8 & 345.7 \\
$\mathrm{ZnO}(8) / F T O$ & 0.606 & 1.577 & 35.77 & 0.341 & 131.4 & 973.1 \\
\hline
\end{tabular}

The reduced charge recombination on the interface of the nano- and micro-structured $\mathrm{ZnO}$ and electrolyte increased the $n$ value and thereby the $V_{o c}$ value. To confirm this, we conducted EIS measurements. EIS is a powerful tool for investigating the charge transport kinetics and the charge recombination in DSSCs [22-25]. The results measured at $-0.7 \mathrm{~V}$ in the dark are shown in Figure S2 in the Supplementary Information section. The Bode phase plots of the EIS spectra for the DSSCs with the $\mathrm{ZnO}(4) / \mathrm{FTO}$ and the $\mathrm{ZnO}(8) / \mathrm{FTO}$ electrodes are displayed in Figure 6a. The EIS Bode phase plots of the DSSCs with the $\mathrm{ZnO}(4) / \mathrm{FTO}$ and the $\mathrm{ZnO}(8) / \mathrm{FTO}$ gave peak frequencies $\left(\mathrm{f}_{\max }\right)$ of 1060 and $277 \mathrm{~Hz}$, respectively. The electron lifetime estimated from the equation $\left(\tau_{n}=1 / 2 \pi f_{\max }\right)[23,24]$ was determined to be 0.150 and $0.575 \mathrm{~ms}$ for the DSSCs with the $\mathrm{ZnO}(4) / \mathrm{FTO}$ and the $\mathrm{ZnO}(8) / \mathrm{FTO}$ photoelectrodes, respectively. A prolonged lifetime (an approximately $380 \%$ increase) of the electrons injected to $\mathrm{ZnO}$ from the dyes was obtained for the $\mathrm{ZnO}(8) / \mathrm{FTO}$ cell, as compared to that of the reference device. The Nyquist plots of the EIS spectra for the DSSCs are presented in Figure $6 \mathrm{~b}$. The Nyquist plots typically include three semicircles: the first semicircle $\left(R_{1}\right)$ corresponds to the redox reaction at the Pt counter electrode, the second one $\left(R_{2}\right)$ corresponds to the electron transfer at the $\mathrm{ZnO} /$ dye/electrolyte interface, and the third one $\left(\mathrm{R}_{1}\right)$ corresponds to the carrier transport by ions in the electrolytes [24-26]. It was noted that by the extended growth time the impedance component of $R_{2}$ in the medium-frequency region was increased. The larger semicircle of $R_{2}$ indicates a more delayed charge recombination at the dye-sensitized $\mathrm{ZnO} /$ electrolyte interface [24,27]. This can be elucidated by the reduced surface area of the $\mathrm{ZnO}(8) / \mathrm{FTO}$, as compared in Figure 2. In other words, by extending the growth time from 4 to $8 \mathrm{~h}$, the number of nanoflowers (high surface area) was decreased, whilst the number of microrods (relatively low surface area) was increased. The decreased surface area induced a reduction of contact area between $\mathrm{ZnO}$ layers and electrolytes, retarding the charge recombination reaction $\left[2 \mathrm{e}^{-}(\mathrm{ZnO})+\mathrm{I}_{3}^{-} \rightarrow 3 \mathrm{I}^{-}\right]$. 

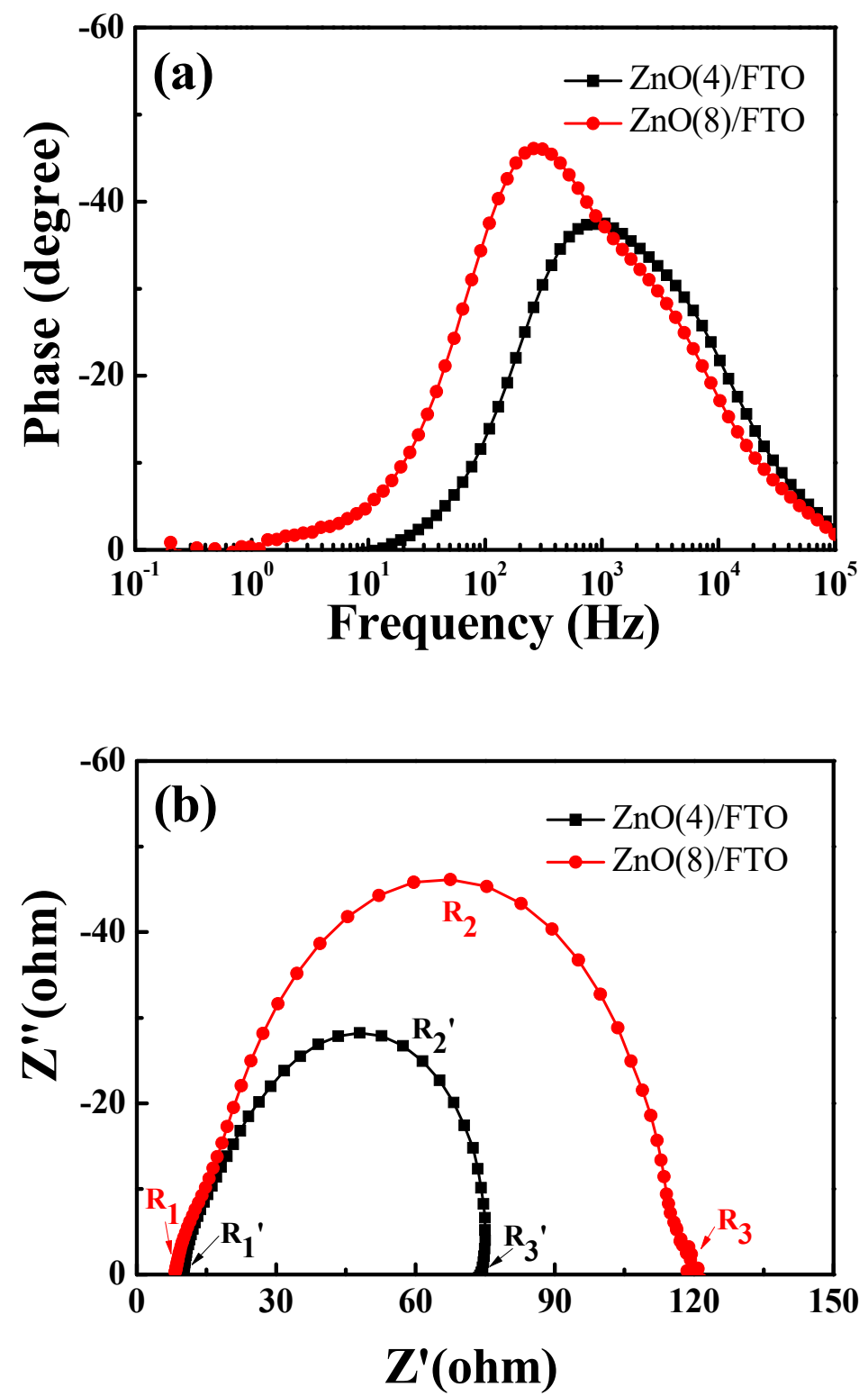

Figure 6. Electrochemical impedance spectroscopic (EIS) spectra of DSSCs with the ZnO(4)/FTO and the $\mathrm{ZnO}(8) / \mathrm{FTO}$ photoelectrodes; (a) Bode and (b) Nyquist plots measured at $-0.7 \mathrm{~V}$ in the dark.

The dark currents can be utilized to evaluate the interfacial charge recombination in DSSCs [27-29]. Increased growth time decreased the dark currents, as illustrated in Figure S3 in the Supplementary Information section. Figure 7 shows the dark currents of the $\mathrm{ZnO}(4) / \mathrm{FTO}$ and the $\mathrm{ZnO}(8) / \mathrm{FTO}$ DSSCs as a function of the applied potential. Throughout the range of measured potential, the dark currents of the $\mathrm{ZnO}(8) / \mathrm{FTO}$ DSSC were lower than those of the reference cell. During measurements of dark currents, electrons injected from FTO to the $\mathrm{ZnO}$ conduction band transferred through the $\mathrm{ZnO}$ layer and then recombined with electrolytes. The lowered current density in the device with the $\mathrm{ZnO}(8) / \mathrm{FTO}$ thus indicated that the charge recombination rate between injected electrons and triiodide ions was retarded compared with the rate of the reference cell with the $\mathrm{ZnO}(4) / \mathrm{FTO}$. The observation of the retarded charge recombination was consistent with the results of the EIS measurements. The prolonged electron lifetime (Bode plots) and the retardation of interfacial charge recombination (Nyquist plots and dark currents) thus indicated that the $n$ value was increased with extended growth time and thereby the $V_{o c}$ value. 


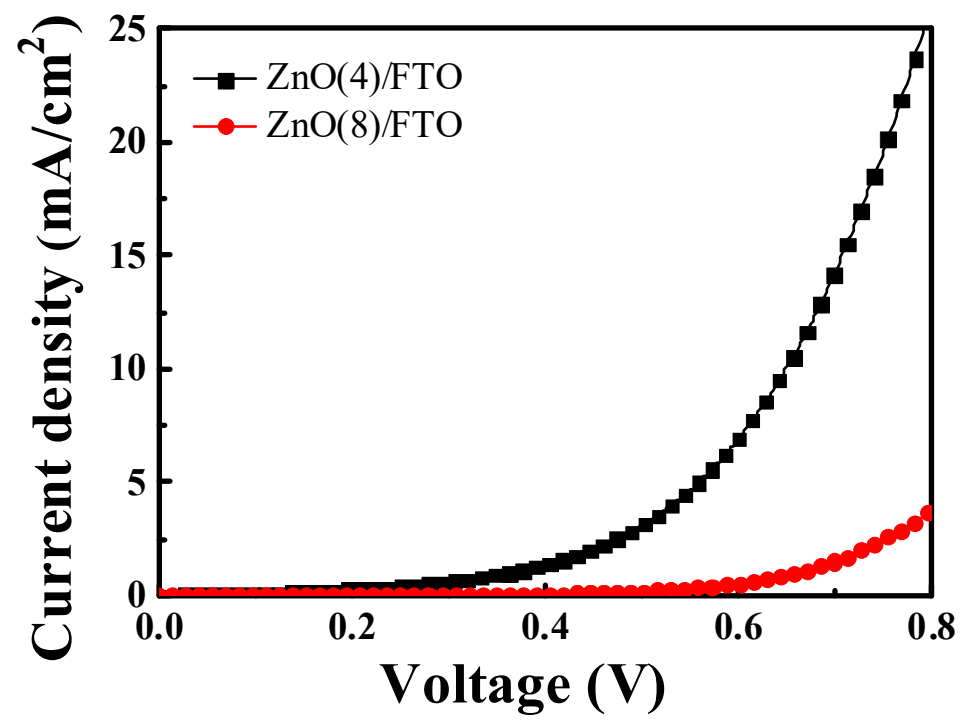

Figure 7. Dark current-voltage characteristics of DSSCs with $\mathrm{ZnO}(4) / \mathrm{FTO}$ and $\mathrm{ZnO}(8) / \mathrm{FTO}$ photoelectrodes.

The $J_{s c}$ value of the $\mathrm{ZnO}(8) / \mathrm{FTO}$ DSSC $\left(1.577 \mathrm{~mA} / \mathrm{cm}^{2}\right)$ is very similar to that of the reference device with the $\mathrm{ZnO}(4) / \mathrm{FTO}\left(1.572 \mathrm{~mA} / \mathrm{cm}^{2}\right)$. The $J_{s c}$ value is determined by Equation $(6)[5,6]$ :

$$
J_{s c}=\int \operatorname{LHE}(\lambda) \cdot \eta_{\text {inj }} \cdot \eta_{\text {col }} \mathrm{d} \lambda
$$

where LHE is the light harvesting efficiency of dyes at a given wavelength $(\lambda), \eta_{\text {inj }}$ is the electron injection efficiency from excited dyes, and $\eta_{\text {coll }}$ is the electron collection efficiencies of the photoinjected electrons to the FTO electrode.

The LHE is related to the light absorbance (A) of the dyes adsorbed on the $\mathrm{ZnO}$ surface, i.e., LHE $=1-10^{-\mathrm{A}}[30,31]$. Thus, the amount of adsorbed dyes should be measured to investigate the effects of the LHE on the $J_{s c}$ value. As mentioned previously, the amount of N719 dyes adsorbed on the $\mathrm{ZnO}(8) / \mathrm{FTO}$ decreased by approximately $60 \%$, compared to the $\mathrm{ZnO}(4) / \mathrm{FTO}$, due to the decreased surface area of $\mathrm{ZnO}$. This indicates that extended growth time could decrease the LHE.

The value of $\eta_{\text {col }}$ depends on the interfacial charge recombination of photoinjected electrons. In other words, more electrons can be collected on the transparent FTO electrode by reducing the charge recombination. As discussed above, EIS and dark current measurements show that by extending the growth time from 4 to $8 \mathrm{~h}$, the lifetime of photoinjected electrons was prolonged and the charge recombination was retarded. This was favorable for increasing the $\eta_{\text {coll }}$ value. Therefore, the $J_{s c}$ value of the cell with the $\mathrm{ZnO}(8) / \mathrm{FTO}$ was similar to that of the reference device because the decrease in the LHE was offset by an increase in the $\eta_{\mathrm{col}}$.

By extending the growth time, the $F F$ value of the DSSC decreased to $35.77 \%$ from $43.94 \%$ of the reference device. Generally, the $F F$ value is influenced by the shunt $\left(R_{s h}\right)$ and series $\left(R_{s e}\right)$ resistances. In other words, an increase of $R_{s h}$ and a reduction of $R_{s e}$, or both, could improve the $F F$ value [32-34]. The $R_{s h}$ and $R_{s e}$ values were acquired from the slope of the $J-V$ curves at $J_{s c}$ and $V_{o c}$, respectively [32,33], as compared in Table 1. The $R_{s h}$ value of the DSSC with the $\mathrm{ZnO}(8) / F T O$ improved by $973.1 \Omega \mathrm{cm}^{2}$ compared to that of the reference cell $\left(345.7 \Omega \mathrm{cm}^{2}\right)$. The increase in $R_{s h}$ can be explained by the delayed charge recombination between photo-injected electrons and triiodide ions in the device with the $\mathrm{ZnO}(8) / \mathrm{FTO}[33,34]$, as demonstrated in both the EIS and the dark current measurements. Meanwhile, the $R_{s e}$ value of the cell with the $\mathrm{ZnO}(8) / \mathrm{FTO}\left(131.4 \Omega \mathrm{cm}^{2}\right)$ was measured to be higher than that of the reference device $\left(97.8 \Omega \mathrm{cm}^{2}\right)$. This can be better explained by the larger gaps between $\mathrm{ZnO}$ microrods in the $\mathrm{ZnO}(8) / \mathrm{FTO}$ than those between nanoflowers in the $\mathrm{ZnO}(4) / \mathrm{FTO}$, causing interruption of electron 
transport. Thus, the elevation of $R_{s e}$, as compared to the reference device, can be attributed to the decrease in the $F F$ value of the $\mathrm{ZnO}(8) /$ FTO DSSC.

\section{Conclusions}

$\mathrm{ZnO}$ nanoflowers and microrods fabricated by $\mathrm{CBD}$ at $90^{\circ} \mathrm{C}$ were sensitized with $\mathrm{N} 719$ dyes and the resulting films were employed for photoanodes of DSSCs. The $\mathrm{ZnO}(8) / \mathrm{FTO} \mathrm{DSSC}$ (microrod-rich) showed a significant increase in the $V_{o c}$ resulting in a PCE of $0.341 \%\left(V_{o c}=0.606 \mathrm{~V}, J_{s c}=1.577 \mathrm{~mA} / \mathrm{cm}^{2}\right.$, and $F F=35.77 \%$ ), as compared to those of the reference $\mathrm{ZnO}(4) / \mathrm{FTO} D S S C$ (nanoflower-rich) (PCE $=0.182 \% ; V_{o c}=0.264 \mathrm{~V}, J_{s c}=1.572 \mathrm{~mA} / \mathrm{cm}^{2}$, and $\left.F F=43.94 \%\right)$. This increase in the $V_{o c}$, and thereby the PCE, was attributed to a retardation of the interfacial charge recombination. This study therefore suggests that the growth temperature and time of $\mathrm{ZnO}$ determine the nanostructure and morphology and $\mathrm{ZnO}$ microrods improve the PCEs of $\mathrm{ZnO}$-based DSSCs more effectively than $\mathrm{ZnO}$ nanoflowers.

Supplementary Materials: The following are available online at http://www.mdpi.com/2079-4991/9/12/1645/s1, Figure S1: $J-V$ characteristics of DSSCs with ZnO/FTO photoelectrodes, Table S1: Photovoltaic parameters of DSSCs with ZnO/FTO photoelectrodes, Figure S2: EIS spectra of the DSSCs with the ZnO/FTO photoelectrodes; (a) Bode and (b) Nyquist plots measured at $-0.7 \mathrm{~V}$ in the dark, Figure S3: Dark current-voltage characteristics of DSSCs with ZnO/FTO photoelectrodes.

Author Contributions: Conceptualization, D.-H.K. and Y.S.H.; formal analysis, S.I.C. and H.K.S.; investigation, S.-J.L. and W.H.K.; writing—original draft preparation, Y.S.H.; writing—review and editing, D.-H.K.

Funding: This work was supported by the KETEP and the Ministry of Trade, Industry \& Energy (No.20173010012980). This work was also supported by the National Research Foundation of Korea (NRF) grant funded by the Korea government (MSIT) (No. NRF-2019R1F1A1058801).

Conflicts of Interest: The authors declare no conflicts of interest.

\section{References}

1. Sharma, K.; Sharma, V.; Sharma, S.S. Dye-Sensitized Solar Cells: Fundamentals and Current Status. Nanoscale Res. Lett. 2018, 13, 381. [CrossRef] [PubMed]

2. Berger, P.R.; Kim, M. Polymer solar cells: P3HT:PCBM and beyond. J. Renew. Sustain. Energy 2018, 10, 013508. [CrossRef]

3. Wang, R.; Mujahid, M.; Duan, Y.; Wang, Z.K.; Xue, J.; Yang, Y. A Review of Perovskites Solar Cell Stability. Adv. Funct. Mater. 2019, 1808843. [CrossRef]

4. O'Regan, B.; Grätzel, M. A low-cost, high-efficiency solar cell based on dye-sensitized colloidal $\mathrm{TiO}_{2}$ films. Nature 1991, 353, 737-740. [CrossRef]

5. Anta, J.A.; Guillén, E.; Tena-Zaera, R. ZnO-based dye-sensitized solar cells. J. Phys. Chem. C 2012, 116, 11413-11425. [CrossRef]

6. Vittal, R.; Ho, K.C. Zinc oxide based dye-sensitized solar cells: A review. Renew. Sustain. Energy Rev. 2017, 70, 920-935. [CrossRef]

7. Bazazi, S.; Arsalani, N.; Khataee, A.; Tabrizi, A.G. Comparison of ball milling-hydrothermal and hydrothermal methods for synthesis of $\mathrm{ZnO}$ nanostructures and evaluation of their photocatalytic performance. J. Ind. Eng. Chem. 2018, 62, 265-272. [CrossRef]

8. Lee, J.; Chae, J.; Nahm, K.; Kang, M. Synthesis of nanometer-sized hexagonal disk-shaped ZnO in formic acid using a hydrothermal method and its optical properties. J. Ind. Eng. Chem. 2009, 15, 645-648. [CrossRef]

9. Memarian, N.; Concina, I.; Braga, A.; Rozati, S.M.; Vomiero, A.; Sberveglieri, G. Hierarchically assembled ZnO nanocrystallites for high-efficiency dye-sensitized solar cells. Angew. Chem. Int. Ed. 2011, 50, 12321-12325. [CrossRef]

10. Tsubomura, H.; Matsumura, M.; Nomura, Y.; Amamiya, T. Dye sensitised Zinc oxide: Aqueous electrolyte: Platinum photocell. Nature 1976, 261, 402-403. [CrossRef]

11. Nayeri, F.D.; Soleimani, E.A.; Salehi, F. Synthesis and characterization of ZnO nanowires grown on different seed layers: The application for dye-sensitized solar cells. Renew. Energy 2013, 60, 246-255. [CrossRef]

12. Chung, J.; Moon, H.; Bhang, S.H.; Kim, W.S.; Bong, K.W.; Yu, T. Aqueous-phase synthesis of single crystal ZnO nanobolts. J. Ind. Eng. Chem. 2016, 36, 59-65. [CrossRef] 
13. Umar, A.; Akhtar, M.S.; Almas, T.; Ibrahim, A.A.; Al-Assiri, M.S.; Masuda, Y.; Rahman, Q.I.; Baskoutas, S. Direct Growth of Flower-Shaped ZnO Nanostructures on FTO Substrate for Dye-Sensitized Solar Cells. Crystals 2019, 9, 405. [CrossRef]

14. Nirmal Peiris, T.A.; Alessa, H.; Sagu, J.S.; Ahmad Bhatti, I.; Isherwood, P.; Upul Wijayantha, K.G. Effect of $\mathrm{ZnO}$ seed layer thickness on hierarchical $\mathrm{ZnO}$ nanorod growth on flexible substrates for application in dye-sensitised solar cells. J. Nanopart. Res. 2013, 15, 2115. [CrossRef]

15. Wang, D.; Zhang, Y.; Su, M.; Xu, T.; Yang, H.; Bi, S.; Zhang, X.; Fang, Y.; Zhao, J. Design of Morphology-Controllable ZnO Nanorods/Nanopariticles Composite for Enhanced Performance of Dye-Sensitized Solar Cells. Nanomaterials 2019, 9, 931. [CrossRef] [PubMed]

16. Peng, T.; Shi, W.; Wu, S.; Ying, Z.; Ri, J.H. Sea urchin-like $\mathrm{TiO}_{2}$ microspheres as scattering layer of nanosized $\mathrm{TiO}_{2}$ film-based dye-sensitized solar cell with enhanced conversion efficiency. Mater. Chem. Phys. 2015, 164, 238-245. [CrossRef]

17. Zaban, A.; Greenshtein, M.; Bisquert, J. Determination of the electron lifetime in nanocrystalline dye solar cells by open-circuit voltage decay measurements. ChemPhysChem 2003, 4, 859-864. [CrossRef] [PubMed]

18. Darvishzadeh, P.; Babanezhad, M.; Ahmadi, R.; Gorji, N.E. Modeling the degradation/recovery of open-circuit voltage in perovskite and thin film solar cells. Mater. Des. 2017, 114, 339-344. [CrossRef]

19. Alarcón, H.; Hedlund, M.; Johansson, E.M.J.; Rensmo, H.; Hagfeldt, A.; Boschloo, G. Modification of Nanostructured $\mathrm{TiO}_{2}$ Electrodes by Electrochemical $\mathrm{Al}^{3+}$ Insertion: Effects on Dye-Sensitized Solar Cell Performance. J. Phys. Chem. C 2007, 111, 13267-13274. [CrossRef]

20. Lee, K.E.; Gomez, M.A.; Charbonneau, C.; Demopoulos, G.P. Enhanced surface hydroxylation of nanocrystalline anatase films improves photocurrent output and electron lifetime in dye sensitized solar cell photoanodes. Electrochim. Acta 2012, 67, 208-215. [CrossRef]

21. Kim, J.T.; Han, Y.S. Effects of surface-modified photoelectrode on the power conversion efficiency of dye-sensitized solar cells. Met. Mater. Int. 2014, 20, 571-575. [CrossRef]

22. Sarker, S.; Seo, H.W.; Seo, D.W.; Kim, D.M. Electrochemical impedance spectroscopy of dye-sensitized solar cells with different electrode geometry. J. Ind. Eng. Chem. 2017, 45, 56-60. [CrossRef]

23. Kim, K.S.; Song, H.; Nam, S.H.; Kim, S.M.; Jeong, H.; Kim, W.B.; Jung, G.Y. Fabrication of an Efficient Light-Scattering Functionalized Photoanode Using Periodically Aligned ZnO Hemisphere Crystals for Dye Sensitized Solar Cells. Adv. Mater. 2012, 24, 792-798. [CrossRef] [PubMed]

24. Zhao, J.; Sun, B.; Qiu, L.; Caocen, H.; Li, Q.; Chen, X.; Yan, F.J. Efficient light-scattering functionalized $\mathrm{TiO}_{2}$ photoanodes modified with cyanobiphenyl-based benzimidazole for dye-sensitized solar cells with additive-free electrolytes. Mater. Chem. 2012, 22, 18380-18386. [CrossRef]

25. Cheng, F.; Ou, Y.; Liu, G.; Zhao, L.; Dong, B.; Wang, S.; Wen, S. Novel quasi-solid-state electrolytes based on electrospun poly(vinylidene fluoride) fiber membranes for highly efficient and stable dye-sensitized solar cells. Nanomaterials 2019, 9, 783. [CrossRef]

26. Kim, J.T.; Lee, S.H.; Han, Y.S. Enhanced power conversion efficiency of dye-sensitized solar cells with $\mathrm{Li}_{2} \mathrm{SiO}_{3}$-modified photoelectrode. Appl. Surf. Sci. 2015, 333, 134-140. [CrossRef]

27. Tian, H.; Hu, L.; Zhang, C.; Liu, W.; Huang, Y.; Mo, L.; Guo, L.; Sheng, J.; Dai, S. Retarded Charge Recombination in Dye-Sensitized Nitrogen-Doped $\mathrm{TiO}_{2}$ Solar Cells. J. Phys. Chem. C 2010, 114, 1627-1632. [CrossRef]

28. Chen, S.G.; Chappel, S.; Diamant, Y.; Zaban, A. Preparation of $\mathrm{Nb}_{2} \mathrm{O}_{5}$ Coated $\mathrm{TiO}_{2} \mathrm{Nanoporous}$ Electrodes and Their Application in Dye-Sensitized Solar Cells. Chem. Mater. 2001, 13, 4629-4634. [CrossRef]

29. Diamant, Y.; Chen, S.G.; Melamed, O.; Zaban, A. Core-shell nanoporous electrode for dye sensitized solar cells: The effect of the $\mathrm{SrTiO}_{3}$ shell on the electronic properties of the $\mathrm{TiO}_{2}$ core. J. Phys. Chem. B 2003, 107, 1977-1981. [CrossRef]

30. Hagfeldtt, A.; Boschloo, G.; Sun, L.; Kloo, L.; Petterson, H. Dye-sensitized solar cells. Chem. Rev. 2010, 110, 6595-6663. [CrossRef]

31. Arkan, F.; Izadyar, M.; Nakhaeipour, A. The role of the electronic structure and solvent in the dye-sensitized solar cells based on Zn-porphyrins: Theoretical study. Energy 2016, 114, 559-567. [CrossRef]

32. Lü, X.; Mou, X.; Wu, J.; Zhang, D.; Zhang, L.; Huang, F.; Xu, F.; Huang, S. Improved-performance dye-sensitized solar cells using $\mathrm{Nb}$-doped $\mathrm{TiO}_{2}$ electrodes: Efficient electron injection and transfer. Adv. Funct. Mater. 2010, 20, 509-515. [CrossRef] 
33. Koide, N.; Islam, A.; Chiba, Y.; Han, L. Improvement of efficiency of dye-sensitized solar cells based on analysis of equivalent circuit. J. Photochem. Photobiol. A 2006, 182, 296-305. [CrossRef]

34. Syrrokostas, G.; Leftheriotis, G.; Yianoulis, P. Effect of acidic additives on the structure and performance of $\mathrm{TiO}_{2}$ films prepared by a commercial nanopowder for dye-sensitized solar cells. Renew. Energy 2014, 72, 164-173. [CrossRef] article distributed under the terms and conditions of the Creative Commons Attribution (CC BY) license (http://creativecommons.org/licenses/by/4.0/). 